\title{
Metabolic Indicators for Pneumonia and Diarrhoea in Holstein Frisian Crossbred Calves
}

\author{
S. Usha ${ }^{1}$, T.K. Mohanty ${ }^{2}$ and P. Senthilkumar ${ }^{3}$ \\ ${ }^{1}$ Post Graduate Research Institute for Animal Sciences, TANUVAS, \\ Kattuppakkam, Chennai, India \\ ${ }^{2}$ Livestock Research Center, National Dairy Research Institute, Karnal-132001, \\ Haryana, India. \\ ${ }^{3}$ Mecheri Sheep Research Station, TANUVAS, Pottaneri, Salem District, Tamil Nadu, India \\ *Corresponding author
}

\section{A B S T R A C T}

\begin{tabular}{|c|}
\hline Keywords \\
\hline $\begin{array}{l}\text { Plasma mineral, } \\
\text { Plasma metabolites, } \\
\text { Diarrhoea, } \\
\text { Pneumonia, } \\
\text { ROC }\end{array}$ \\
\hline Article Info \\
\hline $\begin{array}{l}\text { Accepted: } \\
22 \text { May } 2018 \\
\text { Available Online: } \\
\text { 10 June } 2018\end{array}$ \\
\hline
\end{tabular}

Present study estimated alteration of certain plasma metabolites (glucose, urea nitrogen, cholesterol, NEFA and NEFA: cholesterol ratio) and minerals $(\mathrm{Ca}, \mathrm{P}, \mathrm{Zn}, \mathrm{Cu}$ and $\mathrm{Mn})$ in healthy calves $(n=96)$, calf with diarrhoea $(n=32)$ and calf with pneumonia $(n=32)$. Plasma glucose was significantly lower both in calves with diarrhoea and pneumonia as compared to health calves $(P \leq 0.05)$. There was lower plasma cholesterol level in pneumonic calves as compared to healthy calves $(P \leq 0.05)$. Plasma BUN, NEFA and NEFA: cholesterol ratio remained similar between healthy and diseased calves. Plasma Ca level in diarrhoea and pneumonia condition decreases significantly than the health calves $(P \leq 0.05)$. In pneumonia condition, plasma $\mathrm{Zn}$ level remained significantly lower than healthy ones $(P \leq 0.05)$. Plasma $\mathrm{Cu}$ level was observed to be significantly lower in both diarrhoea and pneumonia condition compared to healthy calves $(P \leq 0.05)$. The plasma $\mathrm{P}$ and $\mathrm{Mn}$ values were similar between healthy and diseased calves. Further, Receiver Operating Characteristic analysis (ROC) revealed that among different plasma metabolites and minerals, plasma glucose is $100 \%$ accurate to differentiate diseased calves from their healthy counterparts. It may be inferred that the levels of glucose would help in differentiate diseased calves from healthy calves in the herd.

\section{Introduction}

Calves are considered as future replacement stocks in a dairy farm, so they are reared economically in a sound manner to ensure early maturity. However, calf hood diseases particularly calf diarrhoea and pneumonia cause considerable economic losses in terms of mortality, morbidity, treatment cost and long term negative consequences on performance in survivours after recovery
(Millemann 2009; Poulsen and McGuirk 2009). In India, incidence of calf diarrhoea and pneumonia within first month has been reported to be $17.77-21.21 \%$ and $7.25-8.51 \%$, respectively in crossbred calves (Brahma and Singh 2007). Therefore, accurate diagnosis followed by proper treatment including management at proper time could help early recovery and reduce long term negative effect on performances. Previous studies reported significant alteration of circulating glucose, 
urea and cholesterol levels in neonatal calf diarrhoea (Chalupnic et al., 2012; Mansour, 2006; Pekcan et al., 2012) and pneumonia (Mansour, 2006; Ragbetli et al., 2010; El-Bahr and EL-Deeb, 2013; Almujalli et al., 2015). Similarly, alteration of circulating macro $(\mathrm{Ca}$ and P) minerals (Cabello and Michel, 1977; Walker et al., 1998) and micro ( $\mathrm{Cu}$ and $\mathrm{Zn})$ minerals (Ghergariu and Kadar, 1979; Ranjan et al., 2006; Soltesova et al., 2015) in calves during diarrhoea has been reported. Further, Ragbetli et al., (2010) reported altered circulating $\mathrm{Ca}$ in pneumonic calves. Hence, there is need to identify the alteration of plasma metabolites and minerals before treatment and supportive therapy of the deficient things would improve recovery of these diseases and would further reduce the negative effect in recovered calves. Present study was designed to estimate certain plasma metabolites (glucose, urea nitrogen, cholesterol, NEFA and NEFA: cholesterol ratio) and minerals ( $\mathrm{Ca}, \mathrm{P}, \mathrm{Zn}, \mathrm{Cu}$ and $\mathrm{Mn}$ ) during neonatal calf diarrhoea and pneumonia. Further, we estimated the accuracy of the parameters to differentiate the diseased and healthy calves.

\section{Materials and Methods}

Present study was conducted on 160 Holstein frisian crossbred calves (96 healthy, 32 diarrhoea and 32 pneumonia) of age within one month at livestock research center, ICARNational Dairy Research Institute, Karnal, India over a period of one year.

Calves were weaned after birth on day zero and housed in a well ventilated pen with straw bedding for 0-4 days and fed colostrum @ $1 / 10^{\text {th }}$ of body weight twice daily by pail feeding per day. Then on $5^{\text {th }}$ day calves were shifted to another pen, where kept upto one month and fed solely with pooled whole milk @ $1 / 10^{\text {th }}$ of body weight per day twice daily.

\section{Disease diagnosis}

Both diarrhoeic and pneumonic calves were diagnosed based on clinical signs. Diarrhoea was diagnosed when a dull and weak calf had frequent defecation, profuse watery faeces with or without mucous/blood, $>8 \%$ dehydration (sunken eyes, loss of skin elasticity). A calf was diagnosed as pneumonic when he/she showed some or all of the symptoms like fever, lack of appetite, ocular/nasal discharge, dullness, dysponea, increased pulse and respiration, cough, enlarged mandibular lymph node and moderate rales on chest auscultation.

\section{Blood sampling, plasma metabolites and mineral estimation}

Approval of Institutes Animal Ethics Committee (IAEC) was obtained for blood collection in the experimental calves. Blood samples were collected using $9 \mathrm{ml}$ blood collection tubes with heparin as anticoagulant (Vacutte ${ }^{\circledR}$, Griner Bio-one Gmbh, Austria) from jugular veinpuncture between 8.30 - 9.30 AM before milk feeding or treatment. Samples were immediately centrifuged at @3000 rpm for 20 minutes at $4{ }^{\circ} \mathrm{C}$ and plasma samples were separated, stored in $2 \mathrm{ml}$ capacity cryovials (Tarson, India) at $-20{ }^{\circ} \mathrm{C}$ until further analysis.

Plasma metabolites; glucose (O-Toluidine end point method, Hultman, 1959), urea nitrogen (Rahmatullah and Boyde, 1980), cholesterol (ferric chloride-sulphuric acid method, Zlatkis et al., 1953), NEFA (modified copper soap extraction method, Shipe et al., 1980) were estimated. Plasma minerals except phosphorus were estimated with the help of Atomic Absorption Spectrophotometer (Philips PU 9100X). Plasma inorganic phosphorus was estimated by standard method given by Fiske and Subbarow (1925). 


\section{Statistical analysis}

The variation of plasma metabolites and minerals were compared by one way analysis of variance (ANOVA) and mean difference between two groups was compared by 'Duncan' post hoc test and considered as significant when $P \leq 0.05$. Further, accuracy of discrimination power of plasma metabolites and minerals to differentiate healthy and diseased calves was estimated by Receiver Operating Characteristic (ROC) analysis (Patbandha et al., 2013). The accuracy in ROC analysis is interpreted based on the area under curve (AUC), which is a 2 dimensional graph (Sensitivity and 1 - Specificity plotted in Yaxis and $\mathrm{X}$-axis, respectively). The AUC must be >0.5, otherwise it is called nondiscriminative or non-informative. If the AUC is $0.5-0.7$ then the diagnostic test has low accuracy, if 0.7-0.9 then moderate accuracy, if 0.9-1.0 then high accuracy and if 1 then it is considered perfect (Swets, 1988; Patbandha et al., 2013).

\section{Results and Discussion}

\section{Plasma metabolic profiles}

Plasma metabolic profile of healthy, diarrhoeic and pneumonic calves is presented in Table 1. There was significantly lower glucose level in calves with diarrhoea and pneumonia as compared to health calves $(P \leq 0.05)$. Hypoglycaemic condition observed in our study is in agreement with previous reports in calf diarrhoea (Mansour 2006; Saleh 2006; Chalupnic et al., 2012; Pekcan et al., 2012) and pneumonia (Sayed et al., 2002; Soltesova et al., 2015). Hypoglycemia condition in diseased calves might be attributed to anorexia condition or less mobilization of glucose from glycogen due to less storage or lower synthesis of glucose by gluconeogenesis (Klein et al., 2002; Pekcan et al., 2012). In diseased animals, anorexia is an adaptive mechanism to combat the disease (Hart 1988). We observed lower plasma cholesterol level in pneumonic calves only but in diarrhoeic calves the concentration was similar to that of healthy calves $(P \leq 0.05)$ which is in accordance with the previous reports (Civelek et al., 2007; El-Bahr and ELDeeb, 2013; Almujalli et al., 2015). The concentration of plasma cholesterol might be associated with inflammatory process or lower secretion in live owing to liver dysfunction (Civelek et al., 2007). Lower glucose level in diseased calves may reduce secretion of cholesterol (Mapiye et al., 2010). In consonance with Soltesova et al., (2015), we did not observe any variation of BUN and NEFA in diseased calves than healthy calves. Although NEFA: cholesterol ratio is a sensitive indicator of energy status in dairy cows but did not show any variation in neonatal calf diarrhoea and pneumonia.

\section{Plasma mineral profiles}

Plasma mineral profile of healthy, diarrhoeic and pneumonic calves is depicted in Table 2. Similar to plasma glucose, $\mathrm{Ca}$ level in diarrhoea and pneumonia condition decreases significantly compared to health calves $(P \leq 0.05)$. Lower plasma $\mathrm{Ca}$ observed in diarrhoea and pneumonia condition is in agreement with other reports (Cabello and Michel 1977; Walker et al., 1998; Ragbetli et al., 2010). Cabello and Michel (1977) reported lower concentration of $\mathrm{Ca}$ in diarrhoeic calves compared to healthy counterparts. However, Walker et al., (1998) observed lower level of $\mathrm{Ca}$ in experimentally induced diarrhoeic calves after 48 hours of induction than before induction. Although, information regarding circulating mineral profiles in calf diarrhoea condition is available, in case of calf pneumonia condition such informations are very less. Ragbetli et al., (2010) stated lower $\mathrm{Ca}$ level in pneumonic calves compared to healthy. Impaired placental transfer of $\mathrm{Ca}$ 
before birth or absorption through intestine after birth may lower plasma level in diseased calves (Cabello and Michel 1977). In pneumonia condition, plasma $\mathrm{Zn}$ level remained significantly lower than healthy ones $(P \leq 0.05)$ which is in consonance with Soltesova et al., (2015), who observed lower $\mathrm{Zn}$ in pneumonic calves. In addition, in human children pneumonia is associated with lower level of $\mathrm{Zn}$ (Arora et al., 2007). Further, plasma $\mathrm{Cu}$ level was significantly lower in diseased calves compared to healthy counterparts $(P \leq 0.05)$. Ghergariu and Kadar (1979) and Ranjan et al., (2006) reported lower $\mathrm{Zn}$ level in diarrhoeic calves than healthy calves. However, plasma $\mathrm{P}$ and $\mathrm{Mn}$ values were similar between healthy and diseased calves. Lower circulating minerals might be attributed to lower intake due to anorexia condition (Soltesova et al., 2015).

Table.1 Plasma metabolic profiles of healthy, diarrhoeic and pneumonic calves

\begin{tabular}{|c|c|c|c|}
\hline Plasma minerals & Healthy $(\mathrm{n}=96)$ & Diarrhoea $(\mathrm{n}=32)$ & Pneumonia $(\mathrm{n}=32)$ \\
\hline Glucose $(\mathrm{mg} / \mathrm{dl})$ & $83.61^{\mathrm{a}} \pm 0.63$ & $51.91^{\mathrm{b}} \pm 1.25$ & $52.77^{\mathrm{b}} \pm 1.40$ \\
\hline BUN $(\mathrm{mg} / \mathrm{dl})$ & $28.24^{\mathrm{a}} \pm 0.36$ & $27.75^{\mathrm{a}} \pm 0.54$ & $28.10^{\mathrm{a}} \pm 0.69$ \\
\hline Cholesterol $(\mathrm{mg} / \mathrm{dl})$ & $99.88^{\mathrm{a}} \pm 1.29$ & $95.52^{\mathrm{a}} \pm 1.80$ & $90.46^{\mathrm{b}} \pm 1.55$ \\
\hline NEIFA $(\boldsymbol{\mu m o l} / \mathrm{L})$ & $222.61^{\mathrm{a}} \pm 9.61$ & $195.49^{\mathrm{a}} \pm 15.86$ & $194.19^{\mathrm{a}} \pm 17.33$ \\
\hline NEFA/Chol & $0.02^{\mathrm{a}} \pm 0.00$ & $0.02^{\mathrm{a}} \pm 0.00$ & $0.02^{\mathrm{a}} \pm 0.00$ \\
\hline Means with different superscript within a row differed statistically $(\boldsymbol{P} \leq 0.05)$
\end{tabular}

Table.2 Plasma mineral profiles of healthy, diarrhoeic and pneumonic calves

\begin{tabular}{|c|c|c|c|}
\hline Plasma minerals & Healthy $(\mathrm{n}=96)$ & Diarrhoea $(\mathbf{n}=32)$ & Pneumonia $(\mathrm{n}=\mathbf{3 2})$ \\
\hline $\mathbf{C a}(\mathrm{mg} / \mathrm{dl})$ & $12.39^{\mathrm{a}} \pm 0.07$ & $12.03^{\mathrm{b}} \pm 0.11$ & $11.75^{\mathrm{c}} \pm 0.10$ \\
\hline $\mathbf{P}(\mathrm{mg} / \mathrm{dl})$ & $5.74^{\mathrm{a}} \pm 0.12$ & $5.53^{\mathrm{a}} \pm 0.19$ & $5.30^{\mathrm{a}} \pm 0.15$ \\
\hline $\mathrm{Zn}(\mathrm{ppm})$ & $1.37^{\mathrm{a}} \pm 0.02$ & $1.29^{\mathrm{a}} \pm 0.03$ & $1.18^{\mathrm{b}} \pm 0.04$ \\
\hline $\mathrm{Cu}(\mathrm{ppm})$ & $1.07^{\mathrm{a}} \pm 0.02$ & $0.93^{\mathrm{b}} \pm 0.03$ & $0.86^{\mathrm{b}} \pm 0.04$ \\
\hline $\mathrm{Mn}(\mathrm{ppm})$ & $0.35^{\mathrm{a}} \pm 0.01$ & $0.36^{\mathrm{a}} \pm 0.02$ & $0.35^{\mathrm{a}} \pm 0.02$ \\
\hline Means with different superscript within a row differed statistically $(\boldsymbol{P} \leq 0.05)$
\end{tabular}


Figure.1 Area Under Curve (AUC) of plasma metabolites during calf diarrhea

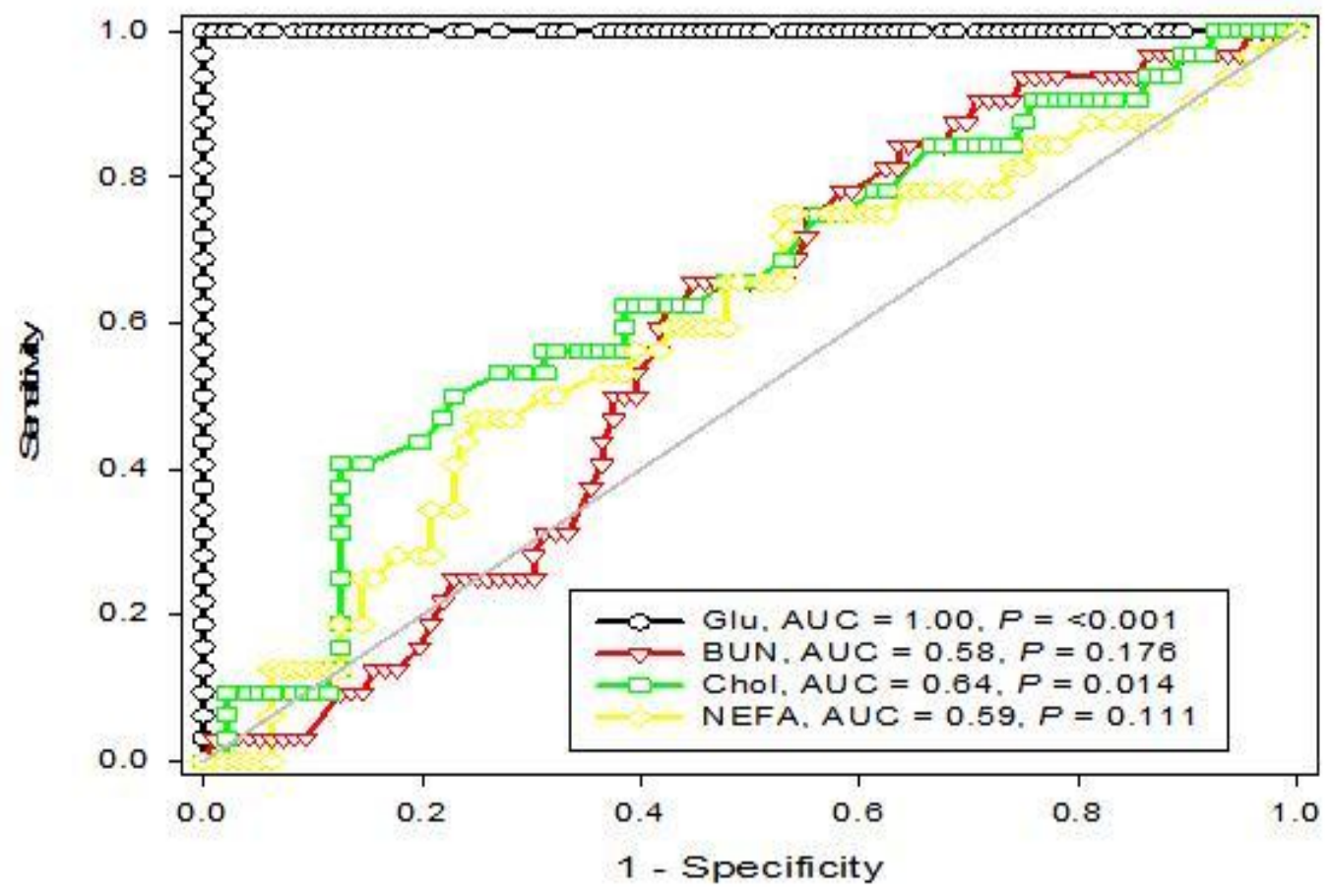

Figure.2 Area Under Curve (AUC) of plasma metabolites during calf pneumonia

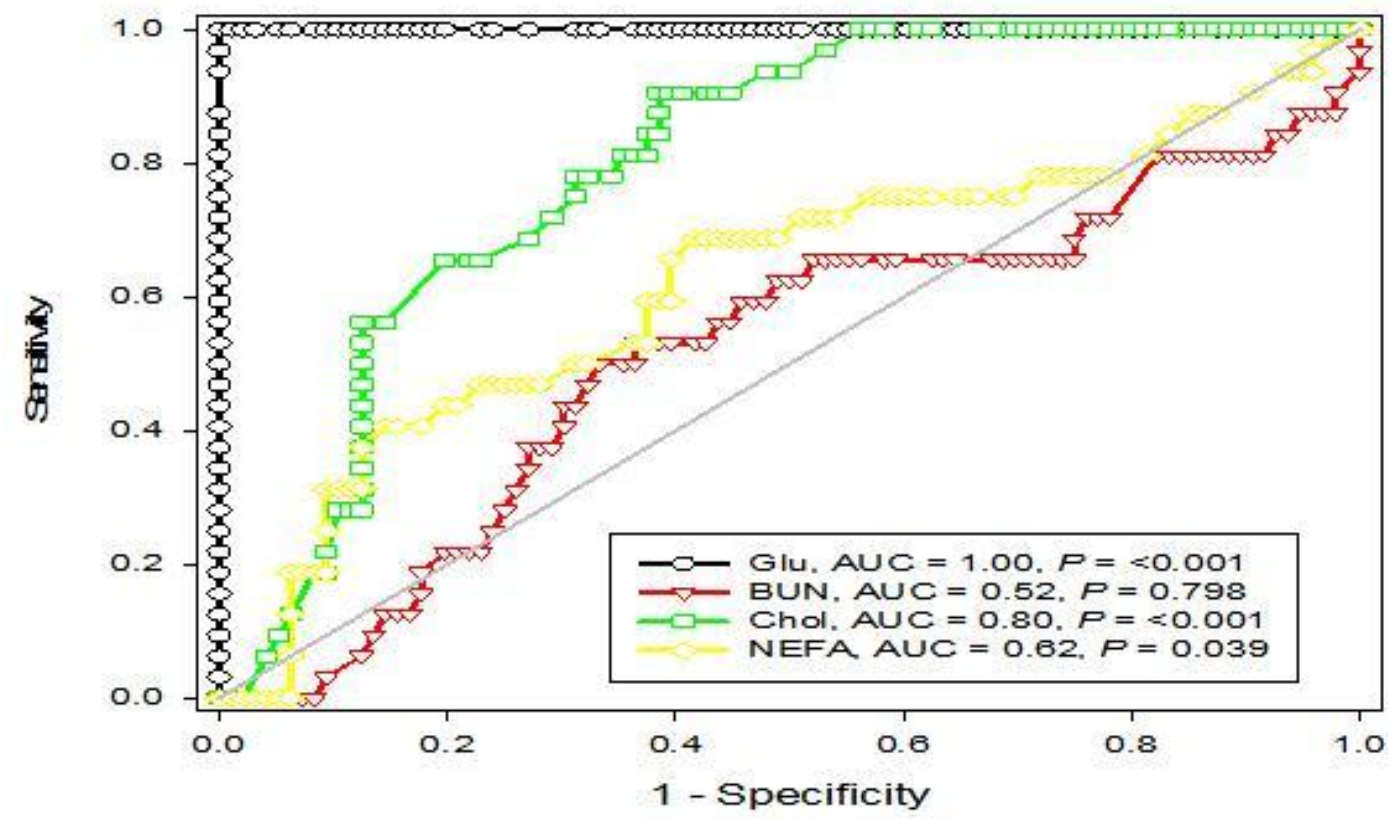


Figure.3 Area Under Curve (AUC) of plasma minerals during calf diarrhea

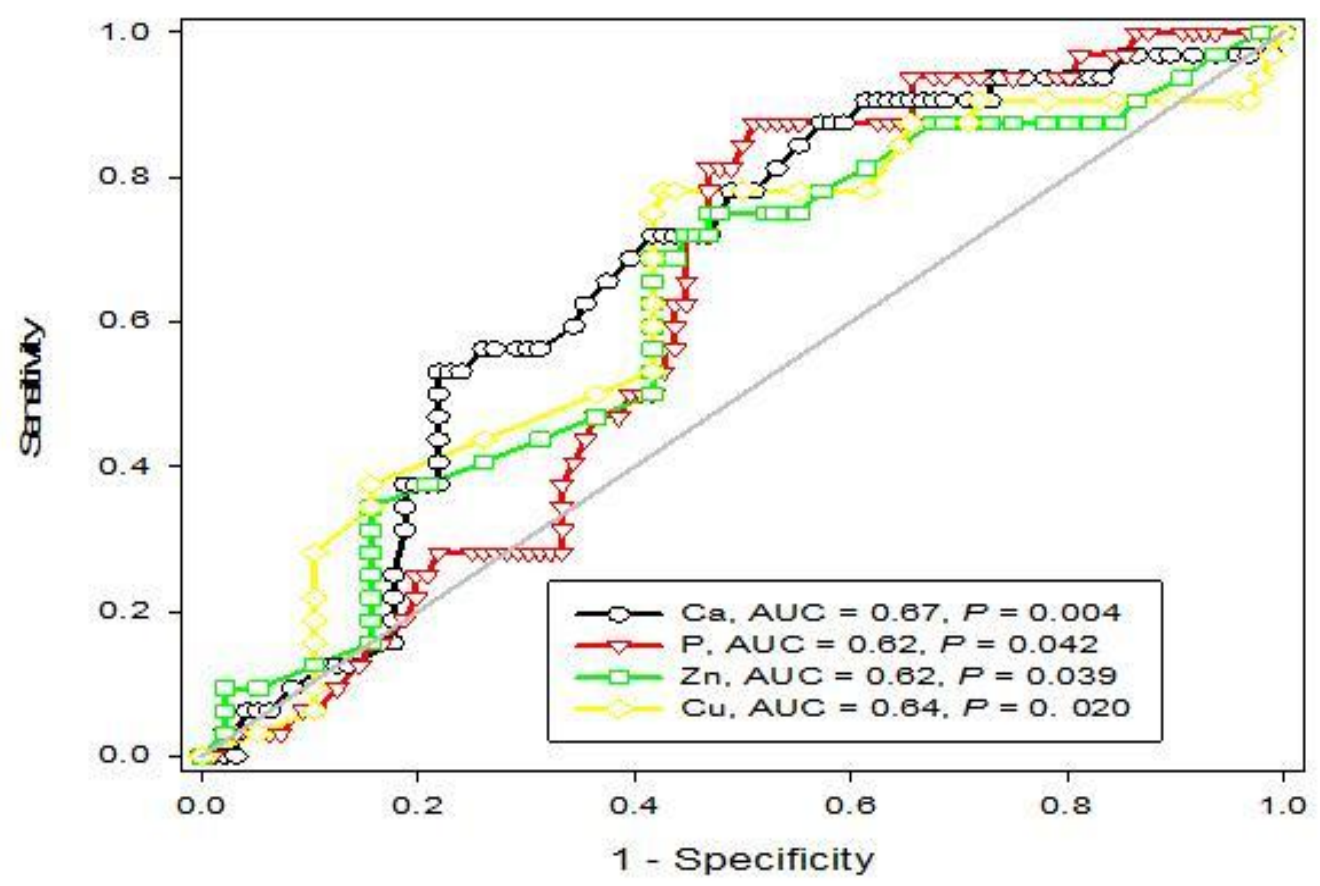

Figure.4 Area Under Curve (AUC) of plasma minerals during calf pneumonia

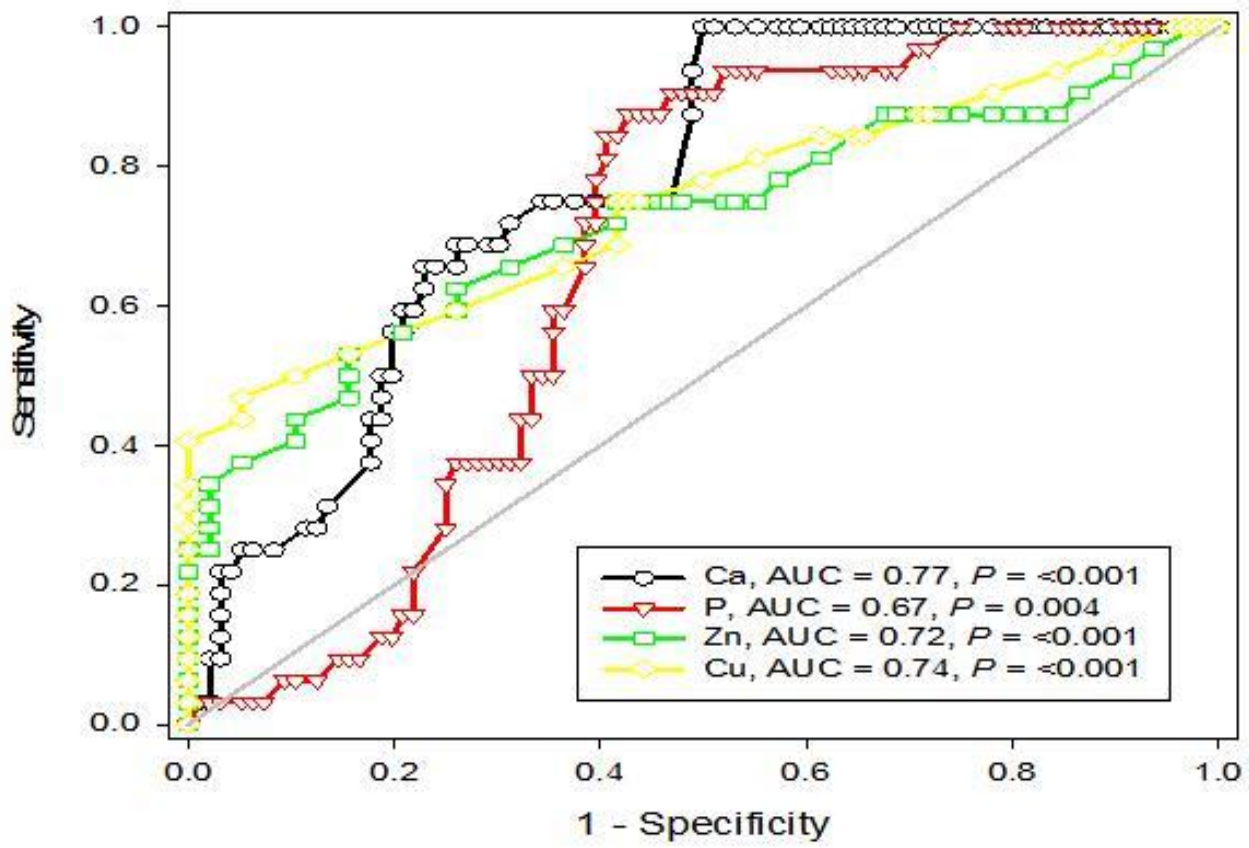


Accuracy of plasma metabolites and minerals

Area under the curve (AUC) is considered as good measure to assess accuracy of diagnostic markers to differentiate diseased and healthy animals as it does not depends on the prevalence of disease (Kumari et al., 2016). Higher the AUC value of a diagnostic marker, then higher is the accuracy to differentiate diseased animals from their healthy counterparts (Swets, 1988; Patbandha et al., 2013). The AUC of the plasma metabolites to discriminate diseased calves from healthy ones are presented in figure- I (diarrhoea condition) and figure- II (pneumonia condition). Further, AUC of the plasma minerals to discriminate diseased calves from healthy ones are depicted in figure- III (diarrhoea condition) and figure- IV (pneumonia condition). Among the different metabolites, plasma glucose differentiated diseased calves (both diarrhoea and pneumonia) from their healthy counterparts with $100 \%$ accuracy $(\mathrm{AUC}=1.0)$. In this study, $100 \%$ accuracy indicated that all calves affected with either diarrhoea or pneumonia had lower level of plasma glucose. On the other hand, none of the plasma minerals had higher accuracy to differentiate diseased and healthy calves (accuracy maximum 67\% in calf diarrhoea i.e. $\mathrm{AUC}=0.67$ and $77 \%$ in calf pneumonia i.e. $\mathrm{AUC}=0.77$ ). The lower intake owing to anorexia condition may lead to hypoglycaemic condition in diseased calves. Hence, by proper supportive therapy could ameliorate hypoglycaemic condition in diseased calves.

Taken together it may be concluded that hypoglycaemia condition occurred in both calf diarrhoea and pneumonia condition. Plasma glucose was $100 \%$ accurate to discriminate diseased calves from their healthy counterparts.

\section{Acknowledgement}

The authors are thankful to Director, National Dairy Research Institute (NDRI), Karnal and Dr. Shiv Prasad, in-charge Livestock Research Center, National Dairy Research Institute, Karnal for providing research facilities.

\section{References}

Almujalli, A. M., El-Deeb, W. M., Eljalii, E. M., Fouda, T. A. and AlBlwy, M. 2015. Clinical, Biochemical and Bacteriological Investigation of Pneumonia in Calves with Special Reference to Alpha-1-Acid Glycoprotein Response. Int. J Vet. Health Sci Res. 3(5), 60-63.

Arora, R., Kulshreshtha, S., Mohan, G., Singh, M. and Sharma, P. 2007. Estimation of serum zinc and copper in children with acute diarrhea. Biol. Trace Elem. Res. 118:184-190.

Brahma, B. and Singh, C. 2007. A study on the health profile of young calves: Influence of genetic and environmental factors. J. Dairying Foods H S 26:9093.

Cabello, G. and Michel, M. C. 1977. Composition of blood plasma (calcium, phosphorus, magnesium, proteins) during the neonatal period in the calf. Influence of the state of health. Ann Rech Vet 8:203-211

Chalupnik, A.D., Herosimczyk, A., Lepczynski, A., Skrzypczak, W.F. 2012. Calves with diarrhea and a waterelectrolyte balance. Medycyna Wet erynaryjna, 68, 1-8.

Civelek, T., Kav, K., Camkerten, I., Celik, A.H. and Acar, A. 2007. Effect of bacterial pneumoniain neonatal calves on serum lipids. Bull. Vet. Inst. Pulawy, 51: 503-507. 
El-Bahr, S.M. and El-Deeb,W.M. 2013. Acute phase proteins, lipid profile and proinflammatory cytokines in healthy and bronchopneumonic water buffalo calves. American Journal of Biochemistry and Biotechnology. 2013;9(1):34-40.

Fiske, C. H. and Subbarow, Y. 1925. The colorimetric determination of phosphorus. J Biol. Chem. 66:375-400.

Ghergariu, S. and Kadar, L. 1979. Behaviour of $\mathrm{Cu}, \mathrm{Fe}$ and $\mathrm{Zn}$ blood level in diseased cattle. I. changes in neonatal diarrhoea. II. changes in respiratory disease in young cattle. Zentralblatt fur Vet 26A: 666-675.

Hart, B.L. 1988. Biological basis of the behavior of sick animals. Neuroscience and Biobehavioral Reviews, 12, 123137.

Hultman, E.1959. Raped specific method for determination of aldohexoses (aldosaccharides) in body fluids. Nature 103:108-109.

Klein, K.A., Clark, C. and Allen, A.L. 2002. Hypoglycemia in sick and moribund farmed elk calves. Canadian Veterinary Journal, 43, 778-781.

Kumari, S., Prasad, S., Patbandha, T.K., Pathak, R., Kumaresan, A., Boro, P., Manimaran, A and Mohanty, T.K. 2016. Metabolic indicators for retention of fetal membranes in Zebu and crossbred dairy cattle. Animal Production Science 56: 1113-1120.

Mansour, A.M.A.E. 2006. Some clinicobiochemical studies on respiratory and digestive troubles in fattening calves with trials of treatment (M.V.Sc. Thesis). Zagazig University, Egypt.

Mapiye, C., Chimonyo, M., Dzama, K. and Marufu, M.C. 2010. Seasonal changes in energy-related blood metabolites and mineral profiles of Nguni and crossbred cattle on communal rangelands in the
Eastern Cape, South Africa. AsianAust. J Anim Sci. 23:708-718.

Millemann, Y. 2009. Diagnosis of neonatal calf diarrhoea. Revue Méd Vét 160:404409.

Patbandha, T.K., Mohanty, T.K., Layek, S.S., Kumaresan, A., Kantwa, S.C., Malhotra, R., Ruhil, A.P. and Prasad, S. 2013. ROC analysis of pre-partum feeding time can accurately predict post-partum metritis development in Holstein Friesian (HF) crossbred cows. J Vet. Behav. 8:362-366.

Pekcan, M., Altintas, A., Karagul, H., Fidanci, U.R., Uysal H., Besalti O., Serap, U.A., Gulay, C., Sibel, B. and Basak, H. 2012. Serum biochemistry and native protein electrophoresis in diarrheic calves with arthritis. Acta Veterinaria (Beograd), 62, 261-269.

Poulsen, K.P. and McGuirk, S.M. 2009. Respiratory disease of the bovine neonate. Vet Clin North Am Food Anim Pract 25:121-137.

Ragbetli, C., Ceylan, E., Tanritanir, P. 2010. The effect of tulathromycin treatment on biochemical parameters in Montofon calves with pneumonia. Asian J Anim. Vet. Adv. 5:169-174

Rahmatullah, M. and Boyde, T.R.C. 1980. Improvement in the determination of urea diacetylmonoxime: Method with or without deproteinization. Clinica Chimica Acta, 107, 3-9.

Ranjan, R., Naresh, R., Patra, R.C., Swarup, D. 2006. Erythrocyte lipid peroxides and blood zinc and copper concentrations in acute undifferentiated diarrhoea in calves. Vet Res. Commun. 30:249-254.

Saleh, G.K.A. 2006. Some clinical and biochemical studies on diarrhoea in early born calves (Ph.D. Thesis). Zagazig University, Egypt.

Sayed, A.S., Ali, A.A., Mottelir and AbdelRahman,

A.A.

2002. 
Bronchopneumonia in buffalo-calves in Assiut governorate. Studies on bacterial causes, clinical, haematological and biochemical changes associated with the disease. Assiut Veterinary Medical Journal, 46, 138-156.

Shipe, W.F., Senyk, G.F., Fountain, K.B. 1980. Modified copper soap solvent extraction method for measuring free fatty acids in milk. Journal of Dairy Science, 63, 193-198.

Soltesova, H., Nagyova, V., Tothova, C. and Nagy, O. 2015. Haematological and blood biochemical alterations associated with respiratory disease in calves. Acta Vet. Brno 2015, 84: 249-256.
Swets, J.A. 1988. Measuring the accuracy of diagnostic systems. Science 240:12851293.

Walker, P.G., Constable, P.D., Morin, D.E., Drackley, J.K., Foreman, J.H., Thurmon, J.C. 1998. A reliable, practical, and economical protocol for inducing diarrhea and severe dehydration in the neonatal calf. Can. J Vet. Res. 62:205-213.

Zlatkis, A., Zak, B., Boyle, C.J., Mich, D.1953. A new method for determination of serum cholesterol. J Lab Clin Med 4:486-492.

\section{How to cite this article:}

Usha, S., T.K. Mohanty and Senthilkumar, P. 2018. Metabolic Indicators for Pneumonia and Diarrhoea in Holstein Frisian Crossbred Calves. Int.J.Curr.Microbiol.App.Sci. 7(06): 3296-3304. doi: https://doi.org/10.20546/ijcmas.2018.706.386 